\title{
DEVELOPING VOCABULARY MASTERY THROUGH GUESSING WORDS GAME FOR THE SEVENTH GRADE STUDENTS OF SMP NEGERI 10 PALU
}

\author{
Arika Nurul Iftitah \\ Abdul Gafur Marzuki \\ Ana Kuliahana \\ English Department and Teacher Training Faculty \\ State Institute for Islamic Studies Palu \\ Arikanuruliftitah@gmail.com
}

\begin{abstract}
The objectives of this research was to know the process of learning English vocabulary by using guessing words game and to know the students' problem in learning English vocabulary by using guessing words game for the seventh grade students of SMP Negeri 10 Palu in academic year of 2019/2020 with the use of guessing words game technique. In this research, the researcher used qualitative research method. The researcher chose class VII D as sample which consisted of 23 students. In collecting the data, the researcher used four kinds of instruments, they were: observation, interview, test and document. Based on the observation, there are some problems in the teaching and learning. To solve those problems, the researcher implemented guessing words game as vocabulary activities. This research was conducted through classroom action research that consisted of two cycles. Each cycles consisted three meetings. The result of the research showed that there were some improvements of the students' vocabulary. In cycle 1 average score was 62,86 there were some unsuccessful score. Meanwhile, in cycle 2 average score was 72,34 the implementation of guessing words game was successful in developing students vocabulary. Guessing words game gives better result to develop the students' vocabulary. In other words, guessing words game is effective to use in teaching English vocabulary.
\end{abstract}

Keywords: Vocabulary, Guessing Words Game, Classroom Action Research 


\section{Introduction}

English serves as a foreign language in Indonesia. In order to be able to communicate in English in responding to global era, Indonesian people should learn English; and the sector to provide Indonesian people with English skill is education. The reason is that it is popularly known that Indonesia people who possess a good command of English are those who have ever entered schools. Based on this, English has become a compulsory subject for students, beginning from those of Junior High School to those of High school in Indonesia.

To achieve the four English skills such as listening, speaking, writing and reading skill, learners of English should first of all have adequate vocabulary. Nevertheless, often students, as learners of English, face the same problems in learning English; they grumble because of their inadequate English vocabulary. Therefore, in teaching English, the teaching of vocabulary should precede the teaching of other aspects of English. It is in this relation that students of Junior High Schools, as English beginners, should be taught how to develop their vocabulary mastery as basic skill to achieve more complex English skills.

Nowadays, teachers of English possess many choices dealing with strategies of developing students' English vocabulary mastery; they can employ such media as videos, films, and games. For this reason, teachers of English have to create innovative strategies of teaching English to students in general and strategies of developing their English vocabulary mastery in particular. Since students' vocabulary mastery, in communication point of view, plays an important role to express their ideas and feelings, and to convey some information to others. Without English vocabulary mastery, students will not be able to achieve other English skills.

The English vocabulary mastery is important to students to achieve the objective of English teaching at Junior High Schools is no longer doubted; their
English vocabulary mastery is a key to master English both spoken English and written English. It is in this context that a research on strategy of developing students' English vocabulary mastery at Junior High Schools need to be conducted.

During the researcher's teaching practice (PPL) at SMP Negeri 10Palu, the researcher observed and found the lack of English vocabulary of the seventh grade students of this school. Therefore, an effort to develop students' English vocabulary is highly needed. In this respect, guessing words game will be employ to develop their English vocabulary mastery.

Playing game in teaching vocabulary is very important because teaching through game can create a fun situation and of course it can increase students motivation. Game does not only help the students encourage their learning but also help the teacher create useful and meaningful context ${ }^{1}$. It means that games can make the students enjoy the English class activities especially in overcoming the problems of learning vocabulary, because they learn in situation where they are given stimulus to practice the English vocabulary.

There are many kinds of games that can be used by the teacher of English to improve students' English vocabulary, such as guessing words game. In this study, guessing words game is chosen as a technique for teaching vocabulary. Guessing words game is one of game techniques which is used to develop the ability in English specially to develop vocabulary. Guess the word is the delivery of teaching material using short words in the form of a game card so that students can receive learning messages through the card. Guessing words game can be played in pairs, or in groups. By playing guessing words game, students can focus more on the English lesson.

1 Tengku Nor Rizanet,et. al, "Young Learners' Perceptions of Learning English Using Language Games in a Non -Formal Context" Mediterranean Journal of SocialSciences. 6 No.6 S5, (2015) 


\section{Review of Related Literatures}

\subsection{Previous Research Findings}

Researches on the attempts of improving English vocabulary among students have been conducted by some researchers; among others were Muhammad Rusyaid, Dewi Nur Halimah and Ika Rahmadani Lubis. In his research, applying jumbled letter game to improve students' English vocabulary Muhammad Rusyaid found that using jumbled letter game could improve students' English vocabulary mastery ${ }^{2}$; and Dewi Nur Halimah research found that applying story telling could improve students' English vocabulary mastery ${ }^{3}$; and Ika Rahmadani Lubis research found that applying fly swatter game was effective in improving students' English vocabulary ${ }^{4}$.

The above three researchers is effective of applying certain strategies (jumbled letter game, story telling, and fly swatter game) to improve students' English vocabulary. Even though this current research is on the developing students' English vocabulary; it is different from the three researches pointed out above because this current research apply guessing words game to develop students' English vocabulary by conducting classroom action research. and write. It means that vocabulary is a centre of all language, it is used by every skills in English. Vocabulary has important role in developing another skills. $^{5}$

\footnotetext{
${ }^{2}$ Muhammad Rusyaid, "Improving the Students' Vocabulary Using Jumbles Letter Game to the Second Grade of MtsKajura, a Thesis (STAIN Watampone 2014)

3 DewiNurHalimah, "Improving the Students' Vocabulary Mastery by Using Story Telling to the Seventh Grade of SMP Ta'mirul Islam" a Thesis(Islamic Institute of Surakarta 2017).

${ }^{4}$ IkaRahmadaniLubis, "ImprovingStudents' Vocabulary Mastery by Using Fly Swatter Game in the First Grade of MTS PAB 1 Helvetia, skripsi (English Department University of North Sumetra Medan 2017).

${ }^{5}$ Jack C. Richard and Willy A. Renandya, Methodology in Language Teaching: An Anthology of Current Practice(New York: Cambridge University Press, 2002), p.255
}

\subsection{Kinds of Vocabulary}

There are at least five kinds of vocabulary; they are as follows:

1. Word Classes

Word classes are as parts of speech such as noun, verb, adverb, adjective, pronoun, preposition and conjunction. In this research, the researcher focused in using noun to teaching vocabulary in junior high school at SMP Negeri 10 Palu. It can be seen from the test in cycle 1 and cycle 2 . Before the students learn about word families, word formation, collocation and homonym, the research want students focused in one theme. It started from noun.

\section{Word Families}

Word families deal with affix and the shift of word. Example:

(a) play-plays-played $=$ inflected

(b)play-replay-playful $=$ derivatives

3. Word Formation

Word-formation can denote either a state or a process, and it can be viewed eitherdiachronicallyor synchronically. For example:

(a). Compounding = second-hand, word processor, typereseacher

(b).Blending $=$ information + entertainment $=$ infotainment

(c). . lipping $=$ electronic mail $=$ email Influenza $=$ flu

4. Collocation

Collocation can be called as two words usually found together. Example

(a).This week, (b).once more, (c).once again, (d).as well.

5. Homonym

Homonym is a word that has the same form but is different in meaning. Example :

(a). well as noun means a shaft usually lined with break or stone, for obtaining water from underground source

(b). Well as adjective means good, right or satisfactory manner

(c). Left as adjective is the opposite of right 
(d). Left as verb is the past form of leave

\subsection{The Importance of Learning Vocabulary in English \\ Why should a learner of English} learn vocabulary? Vocabulary is more important to students than grammar for communication purpose, particularly in the early stages when students are motivated to learn and study English automatically they need additional vocabulary to become more proficient in their own choice of words and expressions ${ }^{7}$.

Learning language cannot be separated from learning vocabulary. Vocabulary supports the speaker to express their opinions, ideas, and feelings in communication. ${ }^{8}$ Vocabulary is one of language elements that important in English. Vocabulary is a microcosm of human consciousness ${ }^{9}$. It means that if the vocabulary is assumed like the cells that make up the organs in the human body, so it is a component of language that we must learn first before the four skills in English.

Without grammar little can be conveyed, without vocabulary nothing can be conveyed. For this reason, a person who wants to be able to communicate in a certain language has to master the vocabulary of that language for the first time.

Vocabulary mastery will make students practice the structure more easily. It is for students in order to communicate in daily life and will strengthen their belief that English can be used to express the same ideas or feelings they express in their native language $\mathrm{e}^{10}$. To make it easy to learn

${ }^{6}$ AS Hornby, Oxford Advanced Learner's Dictionary of Current English (third edition). New York: Oxford University Press, 1974), 483

${ }^{7}$ Roger Gower. et. al. Teaching Practice Handbook, (Thailand:Macmilan, 2005), 42

${ }^{8}$ Nurdin, N. (2009). Segregasi Dalam Pengajaran Dan Penguasaan Bahasa. MUSAWA, 1(1), 23-41.

${ }^{9}$ Scott Thornbury, How To Teach Vocabulary (England: Pearson Education Limited, 2002).1

10 Arum Nisma Wulanjani, "The Use of Vocabulary-Games in Improving Children's
English vocabulary, the researcher will apply guessing word game. Guessing words game is one of games technique which is use to develop the ability in English specially to develop vocabulary because students' will be focus about one theme that teacher gives in every meeting. This game need one person to explaincharacteristic of the theme and the others will guess what the word is.

Guessing words game can play two persons or a group. In learning new language, learners would apply as many strategies as possible in order to master the target language in the shortest time possible. Most of the strategies practiced are usually focusing on the vocabulary acquisition. The reason is that vocabulary is the smallest unit learners need to know in order to use the target language properly ${ }^{11}$.

\section{Methodology}

\subsection{Research Design}

In conducting this research, the researcher employed classroom action research (CAR). Action research is conducted by teachers who want to do something to improve their own situation. ${ }^{12}$ To college the data this research is used qualitative research.

\subsection{Research Subject}

In this research, the researcher took the sample on the students of seventh ' $D$ ' grade at SMP Negeri10 Palu.

\subsection{Procedures of Data Collection}

The procedure of this action research for each step can be described as follows:

The researcher identified the students' problem. The problem which include factor causing the lack of vocabulary of the students. In this research, the researcher

\footnotetext{
Vocabulary in English Language Learnin"g,Transformatika12, Nomer 1, Maret (2016).

${ }^{11}$ Ismail, N. S., Zaid, S. B., Mohamed,M.H., \& Rouyan, N. M. "VocabularyTeaching and Learning Principles in Classroom Practices". Arab World English Journal, 8 (3). (2017)

${ }^{12}$ Sagor, R. How to Conduct Collaborative Action Research. ASRD. (Alexandria. Virginia: USA 1993),70
} 
used several instrument in collecting the data, the problem identified by using four techniques, they are:

\section{a. Observation}

The researcher observed the event in class during the lesson or the treatment using check list to get the data. Observation checklist is used to make the observation process easier, the aspect that observed are concern to teacher explanation, being enthusiastic, seriousness in discussion, responding to question, asking question and accomplishing the task.

\section{b. Interview}

There 2 kinds of interview which were used. They are: structure interview and unstructure interview. ${ }^{13}$

c. Test

A test supposed to be able to measure learning outcome which distinguish the every single student's ability between students already mastered and those who has not yet mastered the learning material.

\section{d. Documentation}

Documentation is gathering evidence and information such as images, record audio, students' worksheet and other reference material. So documentation is important data collection that supports the completeness and accuracy of research data.

\subsection{Procedure of Classroom Action Research \\ There are four components in one cycle for doing classroom action research. It consists of 4 steps:}

1. Planning: Plan as the first step of research to identified the problems. It is a plan to conduct treatment. So, it can improve students' vocabulary. Planning means make a plan for the action that would be conducted in order to improve learning practice, in details and clear manner. This planning is made based on the problems encountered. Action means

\footnotetext{
${ }^{13}$ Suharsimi Arikonto, ProsedurePenelitian,(jakarta: RinekaCipta, 2010), 172
}

perform the planning. Generally this action is in form of learning using certain method according to the planning, which according to researcher assumption has benefits. ${ }^{14}$

2. Acting: After planning the concept, the researcher carried out the treatment referring to the plan has been made. The researcher conducted a pre-cycle before applying the treatment.

3. Observing: Observation is the activity of observing the data collected in order to know learning method, students would be able to increase their vocabulary ability. What extent the action activities have reached the objectives of the study. In this step, the researcher identified and analyzed the data collected during the treatment.

4. Reflecting: Reflecting is the activity of evaluating critically the progress of change of the students' in this step, the researcher observed whether the action has obtained improvement. To support the study, the researcher used interview and test to gather the data. ${ }^{15}$

\subsection{Technique of Analyzing Data from the Observation}

The observation in this research conducted three times, before the treatment or preliminary research, during cycle 1 and cycle 2 . The researcher check observation checklist, and then analyzed by calculating the percentage from the checklist using as the pattern below:

Percentage $\%=n: N x 100100 \%$

$\mathrm{n}=$ the score of student

$\mathrm{N}=$ the sum of total score

$\%=$ the percentage of the explanation

\footnotetext{
${ }^{14}$ Jean McNiff, Action Research : Principle and Pracice, ( LondonMacmillan Education, Ltd. 1988), 28

${ }^{15}$ Kemmis, Stephen, McTaggart, Robin, The Action Research Planner, (Victoria: Deakin University. 1999), 10
} 


\section{Findings and Discussion}

In this part the researcher discusses about the finding of the process in learning vocabulary and the students' problem in learning vocabulary by using guessing words game. The research findings present the description of reconnaissance and the implementation of the action in the teaching learning process there are two cycles in teaching learning process, each cycle divided into three meetings.

\subsection{Reconnaissance}

In this step, the researcher identified problems which occurred in the English teaching learning process at the seventh grade of SMP Negeri 10 Palu. The researcher identified problems related to the teaching vocabulary. The field problems were collected through a classroom observation, and interview. Observation: The observation started on Wednesday, August $7^{\text {th }}, 2019$. In the Process of Learning English Vocabulary by Using Guessing Words Game: The researcher employed an observation to know how is the process of learning English vocabulary by using guessing words game and the problem that may rise in the process of learning. The observation conducted in Three meetings, in cycle 1 the researcher combine all the theme in third meeting. The result were, the students still confused although the researcher had to explained, some of students not focus and not interested because many vocabulary they should master it. In cycle 2 the researcher divided the vocabulary for each meeting, the result is the students' vocabulary increased.

The researcher asked the students' about their impression in learning English. As Andini's statement;

"I think learn English easy sometimes it is hard. Hard because many vocabularies teacher give and the material given by the teacher it is too much in 1 meeting' it made me difficult to learn English" 16

Shinta stated that;

"In my opinion good or not for learn English it is depended on the teacher. Sometimes the teacher teaching by public speaking model, and it made me not interested. But, if the teacher good for using technique it made me understand well and I am very excited to learn English" 17

Yusran's statement;

"In my opinion learning English is easy and memorable in my life because all the time I got a good teacher with good techniques and that made me always excited about learning English"18

From the students' statement above the researcher found Andini difficult learning English because the material is to much in one meeting, Shinta difficult learn English because the teacher not good used technique, and Yusran interested in learning English is from the way the teacher used the techniques. Three statements can influence the students' in learning English.

The researcher asked the teacher's difficulty during teaching vocabulary process:

The teacher's statement;

"The students difficult memorize vocabulary, and still low in vocabulary because are the students in SMP Negeri 10 Palu it's from the school that not learn English well in elementary school. It's made the teacher difficult to explain material" 19

After doing the observation, interviewing the English teacher and some of students, the researcher did conclusion about the problems occurred in the class. Based on the conclusions, the researcher identified some problems that were found

\footnotetext{
${ }^{16}$ Andini, Interviewed on August $07^{\text {th }} 2019$

${ }^{17}$ Shinta, Interviewed on August $07^{\text {th }} 2019$

${ }^{18}$ Yusran, Interviewed on August $07^{\text {th }} 2019$

19 Muzna, Interviewed on August $08^{\text {th }} 2019$
} 
in the field. Firstly, the students difficult to memorize because many vocabularies, secondly, the teacher did not good for using technique it made the students not excited to learn, thirdly, the teacher taught the students by public speaking model and students can not memorize according to vocabulary order or by random an the last students difficult memorize vocabulary, and still low in vocabulary because are the students in SMP Negeri 10 Palu it's from the school that not learn English well in elementary school.

After the field problems were identified, the researchers were focused on teaching technique and the students. The problems were taken because it affected the students' vocabulary. Therefore, the problems needed to be solved soon. It was expected that solving the problems carried out improvements to their vocabulary.

\subsection{The implementation of action}

After knowing the situation of the students, the researcher implemented the action by teaching vocabulary through guessing words game. The classroom action research covered two cycles. Each cycle consisted four steps which include: 1.planning the action, 2.Implementation the action, 3.observing the action, 4.reflecting the observation result. Every cycle was held in three meetings, and every meeting spent about 60-90 minutes. Topics discussed in the first and second cycle about animals, family members, things in the classroom, name of day, name of month, and numbers. It was undertaken from Thursday $22^{\text {th }}$ august until $12^{\text {th }}$ September 2019.

The more detail description of the implementation can be seen in the following section.

\section{a. Cycle 1}

\section{1). Planning the action}

The action plan for the first cycle was made based on the problem identified. The researcher conducted an action by using guessing words game to developing students' vocabulary. Before the action was implemented, the researcher prepared the lesson plan and everything related to action research. The researcher' explained how to play guessing words game:

Firstly: before play guessing words game the students' should memorize vocabulary two meetings, the researcher gave all the text about vocabulary. After the students' mastery all vocabulary, the researcher started a game and combine all theme in third meeting. The researcher divides students into two groups. The researcher' random all vocabulary card in third meeting, one of students' in group should take it and explain the characteristics with all students. And all groups should guess it.

\subsection{Implementation the Action}

In the first cycle, the researcher explained about what is vocabulary, gave an example and the function. Each cycle was conducted in three meetings. The action was divided in there terms, namely opening, main activity, and closing.

\section{a. First meeting \\ 1). Opening}

The first meeting was conducted at 08.00-09.00 on Thursday, August $22^{\text {th }}$, 2019. The topic of vocabulary was memorizing the name of animals, name of month and things in the classroom. The researcher began the activity by greeting the students (warming up), checking their attendances, explaining the objective/background of learning, the benefit of learning, and preparing the students to learn. This initial activity was carried out with the aim of attracting the attention of students, fostering student learning motivation and providing references about learning to be carried out. This activity consists of 2 sessions consisting of the meaning of words, and how to pronounce vocabulary, in this session students listen and repeat the researcher's pronunciation.

\section{2). Main activity}

The researcher asked the students what is vocabulary? Some of students 
answer vocabulary it has a word in sentences that have meaning and divided into 2 words, standard and non standard. And the researcher test one word, what is cat in Indonesian? The students answer 'kucing'. Good students, it is the example from vocabulary. The researcher test students' vocabulary before giving out the vocabulary to be learned. The function is to see the extent the students' abilities. And the researcher distributed papers containing all vocabulary, because the theme at the first meeting about animals, name of month and things in the classroom, the researchers focus reads a loud about animals, name of month and things in the classroom and the students should follow it. This technique is useful so that students can memorize easily and good pronounce. And the last the researcher asked the students to focus and memorizing by themselves. For those who have memorized come forward to memorizing front of the researcher.

\section{3). Closing:}

Before the researcher closed the class, the researcher told the students memorize family members, name of day and numbers for next meetings by good pronounce, and understand the written. And the chairman prepared the class to pray before they go home.

\section{b. second meeting 1). Opening}

On Friday, 23 ${ }^{\text {th }}$ August 2019, the researcher started the lesson at 08.00-09:55. The topic of vocabulary was memorizing the name of family members, name of day and numbers. In this activity, the researcher began the teaching by greeting/ warming up, checking students attendances, explaining the objective/ background of learning, the benefit of learning, and preparing the students to learn. The chairman lead prayed before they were studied.

\section{2). Main activity}

The researcher asked to students, what material we learned yesterday? Did you remember? And the students answer' memorize the vocabulary according to the book's guidelines'. What they are? Students answer, about animals, name of month and things in the classroom. Good students! The researcher asked students, what vocabulary you should memorize today? And the students answer about family members, name of day and numbers. The researcher reads aloud about the theme. And students follow it. After the students understand and memorize. The researcher called the students' name. And the students go forward to memorize vocabulary

\section{3). Closing}

Before the researcher closed the class, the researcher ask the students, what the subject that we have been learn today? And the students answer, today we learned about name of family members, name of day and numbers. The researcher ask some of vocabulary, the students can answer. The chairman prepared the class, pray and say thank you to the researcher.

\section{c. Third meeting 1). Opening}

On Thursday, $29^{\text {th }}$ August 2019, the researcher started the lesson at 08.00-09:00. The topic of vocabulary is playing guessing words game about the name of Animals, family members, name of month, name of day, numbers and things in the classroom. The researcher began the teaching by greeting/ warming up, checking students attendances, explaining the objective/ background of learning, the benefit of learning, and preparing the students to learn. The chairman lead prayed before they were studied.

\section{2). Main activity}

The researcher asked students, what material we learned yesterday? Students answer family members, numbers, and the name of the day. The researcher asked student one by one about the material. The example 'what do you say in Indonesia sister? Or what do you say in English saudara laki-laki'? The students can answer. Before the researcher started the game, the researcher repeating vocabulary from the first cycle and second cycle it to made students memorize well and 
understand all vocabularies. Then the researcher divided 2 game groups based on their name order in the absence list. Therefore, the students were not free to choose which group they liked best to involve.

The reason for using this technique of grouping was train the students to help their friends to guess the word. The game started, the researcher' randomize all vocabularies, the researcher chose one of students go forward took one card and describe the characteristics and another students guess it. The game finished and the researcher tested the students by multiple choice questions essay and matching questions. Based on the observation, it was found that most of students still lack vocabulary. Some of them could finish the work in short time but some could not.

\section{3). Closing}

Before the researcher closed the class, the researcher ask the students. What the subject that we have been learn today? The students' mention, today we learned about name of day, name of month, family members, animals, things in the classroom and numbers. The researchers tried to remind the students' vocabulary before they go home. The chairman prepared the class, pray and say thank you to the researcher.

\section{a). The Students' English Achievement In Cycle 1:}

Table I total students successful are 10 and unsuccessful are 13.

Table I

Students' result in cycle 1

\begin{tabular}{|l|l|l|l|l|l|l|}
\hline $\begin{array}{l}\mathbf{N} \\
\mathbf{0}\end{array}$ & Name & $\begin{array}{l}\text { Essay } \\
\text { score test }\end{array}$ & $\begin{array}{l}\text { Matching } \\
\text { score } \\
\text { test }\end{array}$ & $\begin{array}{l}\text { Totaled } \\
\text { correct } \\
\text { essay test and } \\
\text { matching test. }\end{array}$ & $\begin{array}{l}\text { Average } \\
\text { score of } \\
\text { students }\end{array}$ & \begin{tabular}{l} 
Category \\
\hline $\mathbf{1}$
\end{tabular} \\
$\begin{array}{l}\text { Abrayam } \\
\text { Ismail }\end{array}$ & 26 & 14 & 40 & 74 & Successful \\
\hline $\mathbf{2}$ & Al-Adlu & 29 & 14 & 43 & 80 & Successful \\
\hline $\mathbf{3}$ & Fauad & 30 & 13 & 43 & 80 & Successful \\
\hline $\mathbf{4}$ & Indra Bayu & 30 & 13 & 43 & 80 & Successful \\
\hline $\mathbf{5}$ & $\begin{array}{l}\text { Moh.Aditya } \\
\text { Saputra }\end{array}$ & 26 & 14 & 40 & 74 & Successful \\
\hline $\mathbf{6}$ & Moh.Yusran & 32 & 14 & 46 & 85 & Successful \\
\hline $\mathbf{7}$ & Rayhan Nasir & 29 & 14 & 43 & 80 & Successful \\
\hline $\mathbf{8}$ & Rizki Akila & 24 & 14 & 38 & 70 & Successful \\
\hline $\mathbf{9}$ & Rizkial Hidayat & 26 & 14 & 40 & 74 & Successful \\
\hline $\mathbf{1 0}$ & Elzi & 10 & 6 & 16 & 74 & Successful \\
\hline $\mathbf{1 1}$ & Moh.Fathir & 26 & 14 & 40 & 50 & Unsuccessful \\
\hline $\mathbf{1 2}$ & Miranti & 19 & 8 & 27 & 30 & Unsuccessful \\
\hline $\mathbf{1 3}$ & $\begin{array}{l}\text { Andini } \\
\text { Anjani }\end{array}$ & 19 & 8 & 27 & 61 & Unsuccessful \\
\hline $\mathbf{1 4}$ & Nabila & 20 & 13 & 33 & 67 & Unsuccessful \\
\hline $\mathbf{1 5}$ & Nur Indah & 22 & 14 & 36 & 61 & Unsuccessful \\
\hline $\mathbf{1 6}$ & Nurul Shinta & 20 & 13 & 33 & 61 & Unsuccessful \\
\hline $\mathbf{1 7}$ & Sigit & 20 & 13 & 33 & 50 & Unsuccessful \\
\hline $\mathbf{1 8}$ & Tiara Bella & 19 & 8 & 27 & 50 & Unsuccessful \\
\hline $\mathbf{1 9}$ & $\begin{array}{l}\text { Tri Nur } \\
\text { Rahmadani }\end{array}$ & 15 & 12 & 27 & 67 & Unsuccessful \\
\hline & & & & & \\
\hline
\end{tabular}




\begin{tabular}{|l|l|l|l|l|l|l|}
\hline $\mathbf{2 0}$ & Tri Rafi Irwan & 24 & 14 & 38 & 46 & Unsuccessful \\
\hline $\mathbf{2 1}$ & Arya & 13 & 12 & 25 & 24 & Unsuccessful \\
\hline $\mathbf{2 2}$ & $\begin{array}{l}\text { Miftahul } \\
\text { Jannah }\end{array}$ & 7 & 6 & 13 & 50 & Unsuccessful \\
\hline $\mathbf{2 3}$ & Ilzayat Gifari & 21 & 14 & 35 & 65 & Unsuccessful \\
\hline & Total & & & & $\mathbf{1 . 4 4 6}$ & \\
& Average score & & & & $\mathbf{6 2 , 8 6}$ & \\
\hline
\end{tabular}

Cycle 1: Total number of essay test is 20 numbers and total matching test is 7 numbers. $20+7=27$ numbers. 1 number correct the score is $\mathbf{2}$, if there is an error writing the score is $=1$. Total essay score: 40 (It is from $2 \times$ total essay test) $2 \times 20=40$ ), totaled Matching score: 14 (It is from $2 \times$ totaled matching test $2 \times 7=14$. If all test correct total score is $=54$.

The example from Al-adlu, look at table I. How Al-adlu got 80 scores? Total correct answer's Al-Adlu is $43: 54 \times 100=80$. From students' data obtained in the first cycle is unsuccessful with average amount: Total score of students' $=1.446: 23$ (total of students) $=$ average score 62,86

Successful percentage $\quad=10: 23 \times 100$ $=43,47 \%$

Unsuccessful percentage $=13: 23 \times 100$ $=56,52$

The average score of students in class seventh D was 62,86 while learning achievement (KKM) of English subject is 70. It can be seen the learning was unsuccessful. From the first cycle it doesn't work well, then researcher continues to second cycle. The researcher tried to makes a discussion with an expert and the English teacher about what step that the researcher did in the next cycle. The result of the discussion were the researcher have to change the management class, and the researcher should made 3 groups to made students not talk too much with their friends, then in next cycle the researcher changed management class. In the first, second and third meeting the researcher should determine the theme to make students focus with that theme and made 3 groups to made students not talk too much. Finally, our discussion finished.

\section{3). Observing the action}

Observing was very important to do, because it was done to know the students' improvement. The researcher observed the whole vocabulary activities by each person. The researchers asked students to memorize the vocabulary. And the researcher got the problems in learning process. The problems in memorize vocabulary are:1). The students lack of vocabulary. The problem students don't know the meaning material on the book.2). Students are not excited to memorize vocabulary. Because it made students bored if researcher didn't know how to using technique.3). The vocabulary too much. Some of students difficult memorize the vocabulary.4). And the way of memorizing students is only fixated by rows of vocabulary.

\subsection{Reflection the Action Result}

From the observing above, it showed that the result of cycle 1 is: 62,86 its needed be improved. The following table shows problem and action related to solved related to the fields problem.

Table 2

Action to Solved the problem

\begin{tabular}{|l|l|l|}
\hline No & Problem & Action \\
\hline $\mathbf{1}$ & $\begin{array}{l}\text { Students have } \\
\text { difficulty } \\
\text { memorizing } \\
\text { if }\end{array}$ & $\begin{array}{l}\text { The researcher } \\
\text { gives an easy way } \\
\text { to memorize by } \\
\text { guiding students to } \\
\text { repeat vocabulary. }\end{array}$ \\
\hline
\end{tabular}




\begin{tabular}{|l|l|l|}
\hline & $\begin{array}{l}\text { vocabulary is } \\
\text { random. }\end{array}$ & $\begin{array}{l}\text { And the Researcher } \\
\text { gave the test to } \\
\text { students and tried } \\
\text { to ask the student } \\
\text { one by one. }\end{array}$ \\
\hline 2 & $\begin{array}{l}\text { The teacher } \\
\text { is not quite } \\
\text { right in } \\
\text { applying } \\
\text { teaching } \\
\text { techniques. }\end{array}$ & $\begin{array}{l}\text { The researcher } \\
\text { gave different } \\
\text { technique to make } \\
\text { student interest and } \\
\text { enjoyable }\end{array}$ \\
\hline
\end{tabular}

\begin{tabular}{|c|c|}
\hline Cycle 1 & Cycle 2 \\
\hline $\begin{array}{l}\text { In teaching } \\
\text { learning process, } \\
\text { the researcher } \\
\text { combines all theme } \\
\text { of vocabulary in } \\
\text { third meeting. It } \\
\text { made students not } \\
\text { focused with one } \\
\text { theme and students } \\
\text { are exhausted to } \\
\text { guess a lot of } \\
\text { vocabulary while } \\
\text { playing. }\end{array}$ & $\begin{array}{l}\text { Changed strategy. } \\
\text { The researcher not } \\
\text { combines all } \\
\text { vocabulary in one } \\
\text { meeting or last } \\
\text { meeting. } \\
\text { playing guessing } \\
\text { word game one } \\
\text { meeting to theme. } \\
\text { It made student } \\
\text { easier to guess the } \\
\text { word. }\end{array}$ \\
\hline
\end{tabular}

In the first cycle the researcher used a technique that was not good because the researcher combined all the vocabulary material at the last meeting. The result the vocabulary is too much it made students exhausted and not focused on 1 theme. To solved the problem the researcher changed teaching technique in cycle 2 with different technique. After the researcher evaluated in first cycle, the researcher found that students' vocabulary results have not increased, then the researcher continues to the second cycle.

\section{b. Cycle 2}

\section{1). Panning the action}

Based on the reflection conducted in cycle 1 , the researcher revised the planning of action. The researcher divided 23 students into two groups based on their name order in the absence list. As a result, the students not focus and talk too much with their friends. Therefore in cycle 2 , the technique of grouping the students was revised. In this case, the 23 students divided into 3 groups.

In cycle 1 the researcher combines all the vocabulary that will be guessed. It is different in cycle 2 , the students guess the word according to the theme to made students focus. In cycle 1 the researcher found the problems, especially in memorizing activity, the students can't not memorize by random. The students' only focus on the vocabulary order. And the others problem is the students still lack in vocabulary.

Before doing the cycle 2, the researcher should create different technique. The researcher changed the way of memorization by repeating, asked students vocabulary random, and playing guessing words game. So students were not focused according to the vocabulary row, and students enjoyed it more in memorizing vocabulary. Before started the game the researcher gives instructions how to play guessing words game.

Process guessing words game in cycle 2: The researcher make 3 groups in this cycle 2 , every groups consist of 8 until 7 students. Every group has one student to come up.Researcher divided the theme of vocabulary in this cycle. In the first meeting the material are animals, name of months, and things in this classroom, second meeting the material are family members, name of days and numbers, and the last meeting the material are animals, family members, name of months, name of days, numbers and thing in this classroom. And the researcher ask one student from each group to come up. Researcher gives the card pictures to the all students came up. One student one card picture. The student that raised their hand and guesses the object correctly wins 2 point for their team. Such as: I am in your classroom my function is to write on the whiteboard what am I? The students from each group have given an opportunity to guess and ask 
questions, one student only has 2 opportunities to ask/guess. After guessing, students who explain vocabulary are replaced with guessers.Every group that can guess the object got 2 points. The first group to reach 10 points wins the game and get a prize.

\subsection{Implementing the action}

\section{a. First meeting 1). Opening}

The first meeting in cycle 2 was conducted at $11.30-12: 15$, on Tuesday $3^{\text {th }}$ September 2019. The topic was 'animals and things in the classroom'. Opening was begun by greeting/warming up, checking the students' attendances.

\section{2). Main activity}

The researcher explaining the objective/background of learning, the benefit of learning, and preparing the students to learn. To attract students' learning interest in the topic of guessing words game, the researcher asked some questions related the material. Such as What kind of animals on this picture?

1. Have you ever seen?

2. Where do you see?

3. Could you explain the characteristics?

4. And do you know what thing is this?

5. What is the function of this thing?

6. Could you explain the characteristics?

If the students did not understand the points of the questions, the researcher sometimes asked them in bahasa. In this activity the researcher tried to make the students be able to construct their knowledge by relating their prior knowledge and experience to the material they learnt.

The researcher gave example how to explain the characteristics of the thing. Firstly the researcher described that thing. Example: This is animal, it is cute animal,

\section{b. Second meeting: \\ 1). Opening}

The action was implemented by the researcher. The topic presented in the cycle 2 is Animals and things in the classroom. The implementation of the action in the cycle 2 consisted of three meetings. Each meeting was divided into three terms, namely opening, main activity, and closing.

you can find them in every where you are, she has 4 legs, the fur is smooth, she has many colors, this picture she has white color. She has a long tail, her voice is meow. Who is she? Example from chair: This thing has 4 legs, if you want to sit down. You will need it. What it is? The students who go forward should describe that thing without say the name of that thing.

After the researcher gave the example characteristic of cat, the researcher divided the students into 3 groups. Each group consist eight students. And the researcher explain' the guessing words game clue. The researcher gave random cards focus with the theme and the researcher chose one student go forward in front the class, choose the card and explain the characteristic the animals and things in the classroom. All groups must guess it and who can answer the question go forward to describe the thing and the researcher gave a prize to the winner group and active students.

\section{3). Closing:}

The researcher asked and discussed about students' difficulties during the learning and teaching process. The researcher concluded the learning material together with the students. The researcher asked the students to find and memorize the meaning of some difficult word related animals such as wolf, lion, and tiger. And the researcher asked students to study about next material they are family members and numbers.

The second meeting was conducted at $08.00-09.00$ on Friday $6^{\text {th }}$ September 2019. The topic is 'family members and 
numbers'. Opening was begun by greeting/warming up, checking the students' attendances.

\section{2). Main activity}

Firstly, the researcher asked students about the material in last meeting. 'Who's still remembered the vocabulary on Tuesday'? Some of students answer, animal and things in the classroom. The researcher asked student. What kind of word difficult you remembered? Some of students answer, they are: giraffe, tiger, and camel. And the researcher asked students to repeat five times so the students can easily to remember.

Secondly, the researcher explaining the objective/background of learning, the benefit of learning, and preparing the students to learn. To attract students' learning interest in the topic of guessing words game, the researcher asked some questions related the material. Such as

1. How many family members do you have?

2. Could you explain the characteristic of your mother and your father?

The researchers choose one person to explain their parents in front of the class. And the researcher asked students to pay attention. The researcher asked student to sit with their groups. The researcher gives random a card focus with the theme and the researcher chose one student go forward to describe the characteristics a thing. All groups must guess it, who can answer go forward. The researcher gave score for group wins and active students.

\section{3). Closing:}

Before the researcher closed the lesson, the researcher asked students one by one about the vocabulary that was learned today. Because vocabulary must repeating so that it is always recorded in memory. The researcher asked students to study about name of month and name of day for next meeting. As usual, the 3). Closing:

Before the ball rang, the researchers review again the lesson. They were pay attention carefully about what we were chairman lead the class before the ball rang.

\section{c. Third meetings: 1). Opening}

The last meeting was conducted at 08.00-09.00, on Friday $13^{\text {th }}$ September 2019. The topic is 'name of month and name of day'. Opening was began by greeting/warming up, checking the students' attendances.

\section{2). Main activity}

The researcher asked students about the material in last meeting. 'Who's still remembered the vocabulary that we learned on $3^{\text {th }}$ September? Some of students answer, family members and numbers. The researcher explaining the objective/background of learning, the benefit of learning, and preparing the students to learn. To attract students' learning interest in the topic of guessing words game, the researcher asked some questions related the material. Such as

1. What do you say in English hari rabu dan kamis?

2. What do you say in English maret, juni dan juli?

The students answer the questions.

The researcher gives the example how to guess the name of day and name of month. Firstly took the card, and guess the meaning of word. The researcher asked student to sit on their groups. The researcher gave random a card focus with the theme. And one of student in a group went forward and took the card. And write down the answer on the whiteboard. After write down the answer, the next group took the card and write down the answer till all group answer. After all finished, the researcher gives the last test to know the students improvement. And the last activity the researcher correction the students answer and gave a gift for wins groups and active students.

learning and give them motivation to use the vocabulary where ever they are. The chairman leads to pray together. 
In cycle 2, the researcher asked back the students' about their impression in learning English. As Andini statement;

"Learning English in cycle 2 is very fun and can be understood because the material taught not combine in each meeting" 20

Shinta stated that;

"Learning English in cycle 2 can make my vocabulary increase. I can know English well" 21

Yusran statement;

"My impression learning English is getting better",22

${ }^{20}$ Andini, Interviewed on September $14^{\text {th }}$ 2019

${ }^{21}$ Shinta, Interviewed on September $14^{\text {th }}$ 2019

${ }^{22}$ Yusran, Interviewed on September $14^{\text {th }}$ 2019 


\section{b). The Students' English Achievement In Cycle 2:}

Below is students result in cycle 2: 13 Students are successful and 6 are unsuccessful.

Table 3

Students result in cycle 2

\begin{tabular}{|c|c|c|c|c|c|c|c|}
\hline $\begin{array}{l}\mathbf{N} \\
\mathbf{0}\end{array}$ & Name & $\begin{array}{c}\text { Multiple } \\
\text { choice } \\
\text { test } \\
\text { score }\end{array}$ & $\begin{array}{c}\text { Essay } \\
\text { test } \\
\text { score }\end{array}$ & $\begin{array}{c}\text { Matchin } \\
\text { g score } \\
\text { test }\end{array}$ & $\begin{array}{c}\text { Totaled correct } \\
\text { of multiple } \\
\text { choice, essay } \\
\text { and matching } \\
\text { test. }\end{array}$ & $\begin{array}{c}\text { Average } \\
\text { score }\end{array}$ & Category \\
\hline 1 & $\begin{array}{c}\text { Abrayam } \\
\text { Ismail }\end{array}$ & 11 & 22 & 10 & 43 & 75 & Successful \\
\hline 2 & Al-Adlu & 9 & 26 & 14 & 49 & 86 & Successful \\
\hline 3 & Elzi & 12 & 28 & 14 & 54 & 70 & Successful \\
\hline 4 & Fauad & 12 & 28 & 14 & 54 & 95 & Successful \\
\hline 5 & Ilzayat Gifari & 11 & 20 & 10 & 41 & 70 & Successful \\
\hline 6 & Indra Bayu & 9 & 28 & 14 & 51 & 95 & Successful \\
\hline 7 & $\begin{array}{c}\text { Miftahul } \\
\text { Janna }\end{array}$ & 13 & 24 & 14 & 51 & 70 & Successful \\
\hline 8 & $\begin{array}{l}\text { Moh.Aditya } \\
\text { Saputra }\end{array}$ & 10 & 20 & 10 & 40 & 75 & Successful \\
\hline 9 & Moh.Yusran & 11 & 28 & 10 & 49 & 91 & Successful \\
\hline 10 & Nabila & 9 & 10 & 10 & 29 & 86 & Successful \\
\hline 11 & Nur Indah & 10 & 20 & 10 & 40 & 70 & Successful \\
\hline 12 & Nurul Shinta & 10 & 20 & 10 & 40 & 81 & Successful \\
\hline 13 & Rayhan Nasir & 10 & 11 & 8 & 29 & 89 & Successful \\
\hline 14 & Rizki Akila & 9 & 10 & 10 & 29 & 70 & Successful \\
\hline 15 & $\begin{array}{l}\text { Rizkial } \\
\text { Hidayat }\end{array}$ & 13 & 26 & 10 & 49 & 86 & Successful \\
\hline 16 & Tiara Bella & 10 & 18 & 12 & 40 & 72 & Successful \\
\hline 17 & $\begin{array}{c}\text { Tri Nur } \\
\text { Rahmadani } \\
\end{array}$ & 10 & 24 & 12 & 46 & 70 & Successful \\
\hline 18 & Tri Rafi Irwan & 13 & 10 & 10 & 33 & 51 & $\begin{array}{l}\text { Unsuccessfu } \\
1\end{array}$ \\
\hline 19 & $\begin{array}{c}\text { Andini Rara } \\
\text { Anjani }\end{array}$ & 13 & 20 & 10 & 41 & 51 & $\begin{array}{l}\text { Unsuccessfu } \\
1\end{array}$ \\
\hline 20 & Arya & 11 & 19 & 10 & 40 & 51 & $\begin{array}{l}\text { Unsuccessfu } \\
1\end{array}$ \\
\hline 21 & Miranti & 10 & 11 & 8 & 29 & 51 & $\begin{array}{l}\text { Unsuccessfu } \\
1\end{array}$ \\
\hline 22 & Moh.Fathir & 9 & 10 & 10 & 29 & 51 & $\begin{array}{l}\text { Unsuccessfu } \\
1\end{array}$ \\
\hline 23 & Sigit & 10 & 20 & 10 & 40 & 58 & $\begin{array}{l}\text { Unsuccessfu } \\
1\end{array}$ \\
\hline & $\begin{array}{c}\text { Total } \\
\text { Average } \\
\text { Score }\end{array}$ & & & & & $\begin{array}{l}1.664 \\
72,34\end{array}$ & \\
\hline
\end{tabular}

Cycle 2: Total number of multiple choice tests is 13 numbers, total essay score test is 15 and total matching test is 7 numbers. $13+15+7=35$ numbers. Multiple choice: if one number correct, the score is 1. Essay and matching test if one number correct the score is $\mathbf{2}$, if there is an error writing the score is $=1$. Total multiple choice score is 13 , total essay test score is 30 , and total Matching test score is 14 (14, It is from total test $7 \times 2=14$. If all correct the score is = 57. The example from Abryam, how 
Abryam Ismail got 75 scores? All scores in multiple choice, essay and matching are totaled. Abrayam correct answer 43:57x100=75. From students' data obtained in the second cycle is successful with average amount: $\quad$ Total $=1.664$ : $23=72.34$ ( 23 is total of students, 72.34 is average score)

Successful Percentage $=17: 23 \times 100 \%=$ $73,91 \%$

In cycle 2 successful percentage 72,34 its improved because in cycle 2 the researcher not combine all vocabulary in each meeting, the researcher divide vocabulary in first meeting, second meeting and third meeting it made the students interested with this technique. While in cycle 1 , the researcher' combine all vocabulary in third meeting it made the students difficult to understand the vocabulary.

Unsuccessful percentage $=6: 23 \times 100=$ 26,08

This cycle has stopped until two cycle because the average value has reached 70 .

The observation result based on the data obtained from the activity of the students from cycle 2. The observation was focused on the procedures how to play guessing words game. The students' and the researchers' performance, the students interested, enjoy and motivation toward the application of guessing words game in learning and teaching vocabulary.

Based on the observation, the researcher reflected the reflection of the cycle 2 as follows: (1) the students can be participant in the situation they wish (2) the students who lack in vocabulary can take part in guessing words game. The researcher use guessing words game to developing students' vocabulary and classroom situation did not bored and become alive. Guessing words game developed the students' active in the classroom even though the situation was noisy. From observation in cycle 2 , the researcher found that students' vocabulary improved, the students interested in learning vocabulary by guessing words game, it can be seen in interview. In this research the researcher stop till cycle 2 .

\section{Discussion}

In this section, the discussion deals with the interpretation of the findings derived from the result average score students through vocabulary. The researcher did the research through observation, interview, and test as instruments to know the process of learning. The researcher found out some result of the research in the process of learning vocabulary by using guessing words game technique in English subject in SMP Negeri 10 Palu. In the observation the researcher observed the process of learning in the classroom, the researcher interviewed the teacher and the students to know the students' problem then the researcher gave test to the students to know their result. Based on observation on page 33 the researcher found the problem. The problems are the students' difficult to memorize, the students' can not memorize randomly, the researcher made confused the students with the technique. From observation above we can see the students' score is improved, average score improved after they were given treatment. The researcher assumes that the technique of guessing words game is really helpful to develop the students' vocabulary. It means the students are motivated during the teaching and learning process in cycle 2 because the researcher' not combine all vocabulary in each meeting. While in cycle 1 the researcher combined all vocabularies.

Based on the results of interviews on page 33, the researchers found information almost all the students in SMP Negeri 10 Palu not learn English in their elementary school so the teacher was difficult to teach English. At the time of the interview students said that the teacher too much giving material and vocabulary. So students had difficulty remembering vocabulary. Guessing words game applied by every students has change to explain 
the word to another students. And another student who knows the answer had chance to hands up and gues the word. The students have to focus to hear the word and guess the vocabulary, so that, this situation can made students enjoy. It means that the guessing words game were helpful in teaching learning vocabulay to the seventh grade students of SMP Negeri 10 Palu.

In teaching learning vocabulary the researcher used pictures and colored card to support the materials as media to made the students more intersted. The improvment the students vocabulary was shown in the result of cycle 2 , most of the students were interested in vocabulary from the researcher explanation. The researcher found that all students looked very enthusiastic in doing the teaching learning process. Teaching using a guessing words game could help the students understand, and memorize well. Besides, the improvement could be seen in their behavior, the students were active and ready in class when the teacher entered and they were asked question when found difficulty about the subject. From my research using a guessing words game could helped the teacher and students in teaching learning teaching process. And from Melsa Dwi Cahyani in her reserach She said that using guessing game in improving vocabulary is effective because the game avoid the boredom in the class. It means that Melsa Dwi Cahyani support this research. ${ }^{23}$

\section{Conclusion}

Based on data analysis on discussion the result of the research shows that guessing words game is the good technique which can be implemented in the process of learning English vocabulary. Guessing words game is not only easy to

\footnotetext{
${ }^{23}$ Melsa Dwi Cahyani w, 'Learning English Vocabulary by using guessing game in the first semester of hotel accomodation the first grade students of SMK Negeri 3 Bandar Lampung,a Thesis (State Islamic University(UIN) Raden Intan Lampung 2017)
}

be implemented both by teacher and students, but also can increase the student' motivation and participation in learning process. Moreover, the students also showed an improvement in their English ability especially their vocabulary

The researcher concludes that after using guessing words game at the seventh grade students of SMP Negeri 10 Palu in academic of 2019/2020 helpful to develop students' vocabulary. It can be seen that the students' prior knowledge of vocabulary before applying guessing words game still low, it is provided by the data that all students almost are not success, only 10 students are successful with average score 62,86. students' achievement in vocabulary after applying guessing words game is significantly develop, it was shown by the data that 17 students are successful with average score 72,34 the data I got all most student got very good score. It means that cycle 2 is higher than cycle 1 .

\section{Suggestion}

The successes in teaching learning is how the teacher present the lesson and uses various technique to manage the class more lively and enjoyable. Based on the findings action research, the researcher would like to put forward some suggestions. First, the students' must find new vocabulary from another source like song, or movie, the students should be feeling confident to apply the words, so that they can improve their ability in learning English. The students should practice the vocabulary that they have learned in real situation, more practice can make their pronunciation, and spelling better. If the students keep doubt to say and apply new word, their ability will never develop

Second, The teacher is expected to know that guessing words game can be reference in teaching vocabulary as one alternative teaching technique and it is not only in teaching vocabulary but also for the others skill. English teachers should 
use an interesting technique to attract students' attention and make the students learn comfortable and relaxed. Finally, the school should provide (LCD), Projektor, and speaker to support the students in learning English

\section{References}

Andini, Interviewed on August 07 2019

Andini, Interviewed on September $14^{\text {th }}$ 2019

Arikunto, Suharsimi Prosedure Penelitian,(jakarta: Rineka Cipta, 2010), 172.

Burns Anne, A.2010, Doing Action Research in English Teaching: A guide for Practitioners. New York: Routledge.

D. Nunan, Understanding Language Classroom. Cambridge; (Cambridge University Press, 1989)

Gower. Et.Al. Roger. Teaching Practice Handbook, Thailand: Macmilan, 2005

Halimah Dewi Nur, Improving the students' Vocabulary Mastery by Using Story Telling to the Seventh Grade of SMP Ta'mirul Islam (Islamic Institute of Surakarta, 2017)

Hornby, AS. Oxford Advanced Learner's Dictionary of Current English $\left(3^{\text {th }}\right.$ edition).New York: Oxford University Press, 1974,483.

Hornby, AS “Oxford Advanced Learner's Dictionary of Current English", English Dictionary ( $5^{\text {th }}$ edition) (Oxford: Oxford University Press, (2010),

Hornby, AS, "The effect of Games on EFL Learners' Vocabulary learning strategies', International Journal 1, no 2, (2012).

Hornby, AS, "The importance of vocabulary in language learning and how to be taught, international journal of teaching and education, vol.III No. 3.(2015)

Lubis Ika Rahmadani, Improving Students' Vocabulary Mastery by using fly swatter game in the first grade of MTS PAB 1 Helvetia. Skripsi unpublished University of North Sumetra Medan: (English Department University of North Sumatra, 2017)

Mc Taggart, $\mathrm{R}$ and Kemmis, S. The Action Research (third edition). Victoria, Australia 3217: Deakin Unviersity Press (1988)

McNiff, Jean Action Research : Principle and Pracice, LondonMacmillan Education, Ltd. 1988.

Muzna, Interviewed on August $09^{\text {th }} 2019$

Nasution. Teknologi Pendidikan. Jakarta: Bumi Aksara, 2005.

Nurdin, N. (2009). Segregasi Dalam Pengajaran Dan Penguasaan Bahasa. MUSAWA, 1(1), 23-41.

Oxford. Learner's Pocket Dictionary, $4^{\text {th }}$ edition, Oxford University Press, 2011.

Pedoman karya ilmiah, Institute Agama Islam Negeri (IAIN) Palu, Sulawesi Tengah, 2015

Rizanet Tengku Nor. 'Young Learners' Perceptions of Learning English Using language Games in a NonFormal Context" Mediterranean journal of social sciences 6 no.6 S5, (2015).

Robin, Mc Taggart, Stephen, Kemmis. The Action Planner, (Victoria:Deakin University.1999)

Rusyaid Muhammad, 2014, Improving The Students' Vocabulary Using Jumbles Letter Game to the second grade of MTS Kajura. Thesis unpublished Watanpone: English Tadris Department State Islamic College (STAIN) Watampone

R. Sagor, How to conduct Collaborative Action Research. ASRD (Alexandria Virginia: USA 1993)

Shinta, Interviewed on August 07 2019

Shinta, Interviewed on September $14^{\text {th }}$ 2019 
Thornbury, Scott. How To Teach Vocabulary England: Pearson Education Limited,2002

W, Cahyani Dwi Melsa ' Learning English Vocabulary by using guessing game in the first semester of hotel accomodation the first grade students of SMK Negeri 3 Bandar Lampung', a Thesis( State Islamic University(UIN) Raden Intan Lampung 2017)

Willy A. Renandya and Jack C. Richard C. Jack, Methodology in Language Teaching: An Anthology of Current Practice (New York: Cambridge University Press, 2002)

Wulanjani, Arum, Nisma The Use of Vocabulary-Games in Improving Children's Vocabulary in English Language Learning, Transformatika, Volume 12, Nomer 1, Maret 2016

Yusran, Interviewed on August 07 2019

Yusran, Interviewed on September $14^{\text {th }}$ 2019

Zaid. S. B. Ismail. N. S., Mohamed,M.H., \& Rouyan, N. M."VocabularyTeaching and Learning Principles in Classroom Practices", Arab World English Journal 8 no 3(2017). 